J. Amer. Soc. Hort. Sci. 115(4):618-622. 1990.

\title{
Gene B Influences Susceptibility to Chilling Injury in Cucurbita pepo
}

\author{
T.G. McCollum ${ }^{1}$ \\ Department of Horticulture and Landscape Architecture, Oklahoma State University, Stillwater, \\ OK 74078
}

Additional index words. summer squash, vegetable marrow, scallop, respiration, ethylene, electrolyte leakage, Cucurbita реро

Abstract. The effects of gene $B$ on susceptibility to chilling injury (CI) in two types of summer squash (Cucurbita pepo L.) were investigated. Two pairs of near-isogenic lines with $(B B)$ and without $\left(B^{+} B^{+}\right)$gene $B$ were included in the study: 'Caserta' $\left(B^{+} B^{+}\right)$and 'Precocious Caserta' $(B B)$ of the vegetable marrow type, and 'Benning's Green Tint' $\left(B^{+} B^{+}\right)$and 'Benning's Yellow Tint' $(B B)$ of the scallop type. Respiration and ethylene evolution at nonchilling temperature were consistently higher in marrows than in scallops. Gene $B$ had no influence on respiratory rates at nonchilling temperatures; however, the presence of gene $B$ enhanced the chilling-induced stimulation of respiration in both marrows and scallops. Temporal differences in the patterns of chilling-induced stimulation of ethylene evolution indicated a greater sensitivity to chilling in marrows than in scallops and in both types in the presence of gene $B$. Electrolyte leakage was decreased by storage at chilling temperature in both marrow genotypes and was not influenced by storage temperature in $B^{+} B^{+}$scallops, but was increased by storage at chilling temperature in $B B$ scallops. Therefore, electrolyte leakage was not a good CI index for these summer squash.

The edible forms of Cucurbita pepo consumed immature are referred to as summer squash, Several summer squash types are recognized based on differences in fruit shape (Paris, 1986). Summer squash are susceptible to chilling injury (CI) when stored at 5C or below (Lorenz, 1951; McCollum, 1989; Men-

Received for publication 5 Sept. 1989. Oklahoma Agr. Expt. Sta. J. Series no 5663. I thank Harry S. Paris, Dept. of Vegetable Crops, Agricultural Research Organization, Newe Ya'ar Experiment Station, Haifa, Israel, for donating the 'Precocious Caserta' and 'Benning's Yellow Tint' seeds used in this study. The cost of publishing this paper was defrayed in part by the payment of page charges. Under postal regulations, this paper therefore must be hereby marked advertisement solely to indicate this fact.

'Assistant Professor. Current address: U.S. Department of Agriculture, Agriculture Research Service, 2120 Camden Road, Orlando, FL 32803. carelli, 1987; Mencarelli et al., 1983; Sherman et al., 1985, 1987). Symptoms of CI in summer squash are discoloration and surface pitting. Variation in susceptibility to CI among summer squash types (Sherman et al., 1987) and cultivars (Sherman et al., 1985, 1987) has been documented.

Gene $B$ of C. pepo conditions for precocious yellow fruit pigmentation (Shifriss, 1981) and has been transferred into all types of summer squash to enhance or alter fruit color (Shifriss, 1988). Gene $B$ is pleiotropic or tightly linked with other genes that can influence the expression of desirable or undesirable traits and the expression of these traits depends on gene $B$ 's interaction with the genetic background (Shifriss, 1981). One reported deleterious effect of gene $B$ is increased susceptibility to CI (Sherman et al., 1985, 1987).

Physiological studies of CI in summer squash are limited 
(McCollum, 1989; Mencarelli, 1987; Mencarelli et al., 1983). Comparisons of physiological changes in response to chilling among different summer squash types are completely lacking. The objective of this work was to determine the effects of gene $B$ on chilling sensitivity in two types of summer squash. Chilling-induced stimulation of respiration rate (Autio and Bramlage, 1986; Chan et al., 1985; Eaks and Morris, 1956; McCollum, 1989), ethylene evolution (Autio and Bramlage, 1986; Chen and Patterson, 1985; McCollum, 1989), and electrolyte leakage (Autio and Bramlage, 1986; Chan et al., 1985; King and Ludford, 1983) have been used as indices of CI in a variety of chilling-sensitive tissues and were used to assess chilling sensitivity in the present study.

\section{Materials and Methods}

Two pairs of near-isogenic lines of summer squash with $(B B)$ and without $\left(B^{+} B^{+}\right)$gene $B$ were included in the study: 'Caserta' $\left(B^{+} B^{+}\right)$(Northrup King, Gilroy, Calif.) and 'Precocious Caserta' $(B B)$ (Paris et al., 1985b) of the vegetable marrow type and 'Benning's Green Tint' $\left(B^{+} B^{+}\right)$(Northrup King) and 'Benning's Yellow Tint' $(B B)$ (Paris et al., 1985a) of the scallop type. Fruit were obtained from greenhouse-grown plants. Female flowers were hand-pollinated on the morning of anthesis. Fruit were harvested $5 \pm 1$ days after anthesis, when fruit weights were 75 to $100 \mathrm{~g}$. Following harvest, the fruit were dipped into water containing $100 \mathrm{ppm}$ free chlorine and then blotted dry.

Rates of respiration and ethylene evolution from the four genotypes were compared during storage at constant, nonchilling (15C) temperature. Five replicate samples (two to three fruit per sample) of each genotype were placed into a controlledtemperature chamber maintained at $15 \mathrm{C}$. Respiration and ethylene evolution were measured after 3, 6, 9, and 12 days at 15C, as described by McCollum (1989). Carbon dioxide in the jars never exceeded $1.0 \%$. Minimum detectable quantity of $\mathrm{C}_{2} \mathrm{H}_{4}$ was $25 \mathrm{ppb}$.

The effects of storage at chilling and nonchilling temperatures on rates of respiration, ethylene evolution, and electrolyte leak-

Table 1. Mean squares from analyses of variance for respiration rate and ethylene evolution from summer squash fruit as influenced by squash type, gene $B$, and duration of storage at constant $15 \mathrm{C}$.

\begin{tabular}{lccc}
\hline \multicolumn{1}{c}{ Source } & df & $\begin{array}{c}\text { Respiration } \\
\left(\mathrm{ml} \cdot \mathrm{kg}^{-1} \cdot \mathrm{hr}^{-1}\right)\end{array}$ & $\begin{array}{c}\text { Ethylene } \\
\left(\mathrm{nl} \cdot \mathrm{g}^{-1} \cdot \mathrm{hr}^{-1}\right)\end{array}$ \\
\hline Replication & 4 & $975.9^{* * *}$ & $1.6^{* *}$ \\
Type (T) & 1 & $22,068.0^{* * *}$ & $94.1^{* * *}$ \\
Genotype (G) & 1 & 65.7 & 1.9 \\
Duration linear (DL) & 1 & $2,194.5^{* * *}$ & $2.4^{* *}$ \\
Duration quadratic (DQ) & 1 & 76.2 & $8.4^{* * *}$ \\
Duration cubic (DC) & 1 & $237.6^{* * *}$ & $3.7^{* * *}$ \\
$\mathrm{~T} \times \mathrm{G}$ & 1 & 3.3 & $1.9^{*}$ \\
$\mathrm{~T} \times \mathrm{DL}$ & 1 & $1,207.2^{* * *}$ & $2.4^{* *}$ \\
$\mathrm{~T} \times \mathrm{DQ}$ & 1 & $162.2^{*}$ & $8.4^{* * *}$ \\
$\mathrm{~T} \times \mathrm{DC}$ & 1 & $159.1^{*}$ & $3.7^{* * *}$ \\
$\mathrm{G} \times \mathrm{DL}$ & 1 & 0.5 & 0.0 \\
$\mathrm{G} \times \mathrm{DQ}$ & 1 & 26.6 & 0.2 \\
$\mathrm{G} \times \mathrm{DC}$ & 1 & 1.6 & 1.2 \\
$\mathrm{~T} \times \mathrm{G} \times \mathrm{DL}$ & 1 & 0.1 & 0.0 \\
$\mathrm{~T} \times \mathrm{G} \times \mathrm{DQ}$ & 1 & 0.8 & 0.2 \\
$\mathrm{~T} \times \mathrm{G} \times \mathrm{DC}$ & 1 & 3.6 & 1.2 \\
$\mathrm{Error}$ & 60 & 26.1 & 0.4 \\
\hline$* * * \mathrm{D}$ & & 0.01 & 0.001 \\
\hline
\end{tabular}

$* * * * * *$ Significance of $\mathrm{F}$ at $P=0.05,0.01$, or 0.001 , respectively. age in the four genotypes were evaluated in a second experiment. Fruit were placed into controlled-temperature chambers maintained at either 5C (chilling) or 12C (nonchilling). Samples of two to three fruit were removed from the temperature treatments after 3, 6, and 9 days. Treatments were replicated over four harvests.

Rates of respiration and ethylene evolution were measured as described above from fruit that were held at $15 \mathrm{C}$ for $24 \mathrm{hr}$ following removal from the temperature treatments. Electrolyte leakage from pericarp disks was measured immediately following removal from the temperature treatments. Pericarp disks were prepared from tissue slices $\approx 10 \mathrm{~mm}$ thick. Disks $(10 \mathrm{~mm}$ in diameter) were removed from the tissue slices with a cork borer, rinsed briefly in deionized water, blotted dry, and weighed. The disks $(\approx 0.5 \mathrm{~g})$ were placed into $25 \mathrm{ml}$ of aqueous mannitol $(0.2 \mathrm{M})$ and incubated at $23 \mathrm{C}$. Conductivity of the bathing solution was measured with a conductivity meter (Markson, Del Mar, Calif.) following a 4-hr incubation. The tissue was then killed by autoclaving for 20 rein, and conductivity was remeasured after incubating the samples for an additional $24 \mathrm{hr}$ at 23C. Electrolyte leakage was expressed as initial conductivity as a percentage of total conductivity.

All data were subjected to analyses of variance. The first experiment was a complete factorial (type $x$ gene $B x$ time) in a randomized complete-block design with five replications. Data from the second experiment were analyzed separately for each squash type (gene $B \times$ temperature $\times$ time); the experimental design was a randomized complete block with four replications.

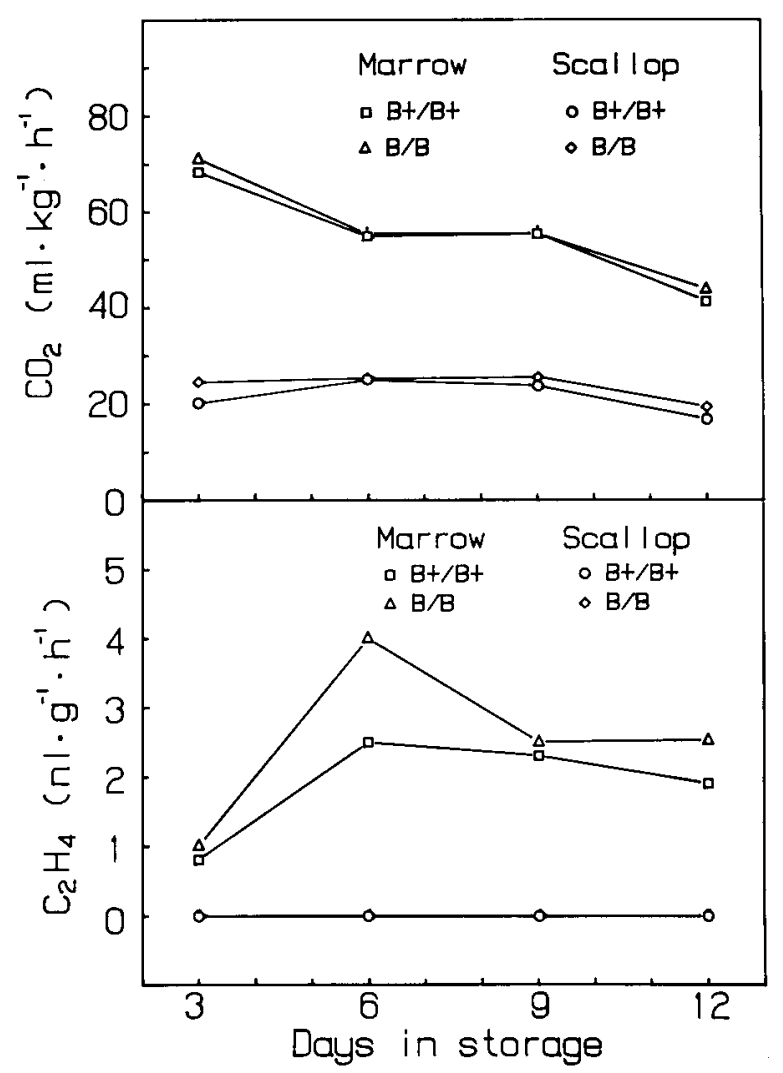

Fig. 1. Rates of respiration (top) and ethylene evolution (bottom) of marrow- and scallop-type summer squash fruit with $(B B)$ and without $\left(B^{+} B^{+}\right)$gene $B$ during storage at constant $15 \mathrm{C}$. Values represent the means of five replicate samples. 
Table 2. Mean squares from analyses of variance for respiration rate, ethylene evolution, and electrolyte leakage of marrow-type and scallop-type summer squash fruit as influenced by genotype, storage temperature, and storage duration.

\begin{tabular}{|c|c|c|c|c|c|c|c|}
\hline \multirow[b]{2}{*}{ Source } & \multirow{2}{*}{$\mathrm{df}$} & \multicolumn{2}{|c|}{$\begin{array}{c}\text { Respiration } \\
\left(\mathrm{ml} \cdot \mathrm{kg}^{-1} \cdot \mathrm{hr}^{-1}\right)\end{array}$} & \multicolumn{2}{|c|}{$\begin{array}{c}\text { Ethylene } \\
\left(\mathrm{nl} \cdot \mathrm{g}^{-1} \cdot \mathrm{hr}^{-1}\right)\end{array}$} & \multicolumn{2}{|c|}{$\begin{array}{c}\text { Electrolyte leakage } \\
(\% \text { total })\end{array}$} \\
\hline & & Marrow & Scallop & Marrow & Scallop & Marrow & Scallop \\
\hline Replication & 3 & $1,377.5^{* * *}$ & $544.2^{*}$ & 3.0 & 5.0 & 74.7 & 72.9 \\
\hline Genotype (G) & 1 & $3,543.2 * * *$ & $7,274.2 * * *$ & $25.8 * * *$ & $90.2^{* *}$ & 97.2 & $840.6^{* * *}$ \\
\hline Temperature $(\mathrm{T})$ & 1 & $15,365.4^{* * *}$ & $19,939.0^{* * *}$ & $56.3 * * *$ & $95.8 * *$ & $787.1 * * *$ & $240.1 * *$ \\
\hline Duration linear (DL) & 1 & $2,021.8^{* * *}$ & $1,129.0^{*}$ & 1.4 & 14.0 & 1.8 & $260.3^{* *}$ \\
\hline Duration nonlinear (DN) & 1 & 393.4 & 142.5 & $7.7^{*}$ & 3.9 & 63.2 & 0.0 \\
\hline $\mathrm{G} \times \mathrm{T}$ & 1 & 438.0 & $2,582.8 * * *$ & 1.2 & $93.7 * *$ & 37.3 & $235.3^{* *}$ \\
\hline$G \times D L$ & 1 & $942.9^{*}$ & 409.0 & 4.1 & 4.1 & 60.7 & $215.6^{* *}$ \\
\hline $\mathrm{G} \times \mathrm{DN}$ & 1 & 2.2 & 122.4 & 0.1 & 13.0 & 0.7 & 1.0 \\
\hline$T \times D L$ & 1 & $2,870.9^{* * *}$ & $3,719.5^{* * *}$ & $17.6^{* * *}$ & 5.9 & 0.5 & $186.4^{* *}$ \\
\hline $\mathrm{T} \times \mathrm{DN}$ & 1 & $1,460.9 * *$ & 431.0 & $10.6 * *$ & 13.5 & 10.7 & 6.3 \\
\hline $\mathrm{G} \times \mathrm{T} \times \mathrm{DL}$ & 1 & $1,337.7^{*}$ & 4.8 & 1.3 & 6.9 & 10.4 & $162.2^{*}$ \\
\hline $\mathrm{G} \times \mathrm{T} \times \mathrm{DN}$ & 1 & 102.3 & 632.4 & 0.0 & 15.8 & 1.6 & 3.9 \\
\hline Error & 33 & 221.3 & 181.6 & 1.5 & 7.9 & 47.1 & 31.5 \\
\hline
\end{tabular}

*,***** Significance of $\mathrm{F}$ at $P=0.05,0.01$, or 0.001 , respectively.

\section{Results and Discussion}

Main effects of squash type on respiration at constant nonchilling (15C) temperature were highly significant (Table 1). Respiration rates of marrows were consistently higher than respiration rates of scallops during storage at 15C (Fig. 1, top). Marrow respiration decreased during 12 days of storage, whereas scallop respiration remained fairly constant. The presence of gene $B$ had no influence on respiratory rates of marrows or scallops at constant $15 \mathrm{C}$. Respiratory rates of scallops were similar, although not directly comparable, to rates reported for zucchini (Mencarelli et al., 1983, Mencarelli, 1987) and yellow crookneck summer squash (McCollum, 1989). The higher respiratory rates of marrows suggests that the potential postharvest shelf life of marrows is less than for scallops. This suggestion is in agreement with the report that marrows have a poorer postharvest storability than scallops (Sherman et al., 1987).

The squash type $\times$ genotype interaction effect on ethylene evolution was significant (Table 1). Ethylene evolution from scallops during storage at $15 \mathrm{C}$ was below the limit of detection, whereas marrows produced appreciable quantities of ethylene (Fig. 1, bottom). Ethylene evolution increased between 3 and 6 days at $15 \mathrm{C}$ in both marrow genotypes, and was significantly greater in $B B$ than in $B^{+} B^{+}$marrows after 6 days. Ethylene evolution from $B B$ marrows decreased after 6 days at $15 \mathrm{C}$ and, thereafter, rates were similar to $B^{+} B^{+}$. Although results were not consistent, data presented by Mencarelli et al. (1983) indicated an increase in ethylene evolution from zucchini during storage at 10C. Poenicke et al. (1977) and Saltveit and McFeeters (1980) reported a similar increase in ethylene evolution in cucumbers following harvest. This increase in ethylene evolution does not represent a climacteric, as there was no corresponding increase in the rate of respiration. Ethylene stimulates respiration in a variety of plant tissues (Abeles, 1973). The higher respiratory rates in marrows may be the result of stimulation by endogenous ethylene.

Surface pitting became obvious on $B B$ marrows after 3 days at $5 \mathrm{C}$ and on $B^{+} B^{+}$fruit after 6 days at $5 \mathrm{C}$. Following transfer to $15 \mathrm{C}$, pitting became more severe. $B B$ marrow fruit stored at $5 \mathrm{C}$ for 6 or more days were considered to be unmarketable due to extensive pitting. Large necrotic areas developed on the surface of $B B$ marrows following transfer from 5 to $15 \mathrm{C}$. Surface pitting did not develop on scallops during storage at 5C. Scal- lops stored at 5C for 9 days developed slight surface pitting after transfer to $15 \mathrm{C}$; however, the appearance of pitting was not obviously different between the two scallop genotypes. Surface pitting was not observed on fruit that had been stored at $12 \mathrm{C}$.

Respiration. Main effects of genotype and storage temperature on respiration rates of marrow- and scallop-type summer squash were highly significant (Table 2 ). Storage at $5 \mathrm{C}$ resulted in a stimulation of respiration in both marrows and scallops (Fig. $2)$. The genotype $\times$ storage temperature $\times$ storage duration linear interaction on respiration rate of marrows was significant (Table 2). The chilling-induced stimulation of respiration occurred at least 3 days earlier in $B B$ marrows than in $B^{+} B^{+}$ marrows, even though the magnitude of the response was similar in the two genotypes (Fig. 2, top). The genotype x storage temperature interaction effect on respiration rate of scallops was highly significant (Table 2). Respiration rates of chilled $B^{+} B^{+}$ scallops were significantly higher than rates of chilled $B B$ scallops (Fig. 2, bottom); in nonchilled scallops, respiration rates were similar for the two genotypes. The chilling-induced stimulation of respiration coincided with the onset of surface pitting in the marrow cultivars, but no surface pitting occurred in scallops. A similar chilling-induced stimulation of respiration has been reported for cucumbers (Eaks and Morris, 1956), zucchini (Mencarelli et al., 1983; Mencarelli, 1987), and yellow crookneck squash (McCollum, 1989). The earlier chilling-induced stimulation of respiration in $B B$ marrows and the greater magnitude of the response in $B B$ scallops indicate a greater sensitivity to chilling in the presence of gene $B$.

Ethylene. Main effects of genotype and storage temperature on ethylene evolution were highly significant in marrows (Table 2). Storage at $5 \mathrm{C}$ stimulated ethylene evolution in both marrow genotypes; however, ethylene evolution was higher in $B B$ marrows than $B^{+} B^{+}$marrows following storage at 5 and $12 \mathrm{C}$ (Fig. 3 , top). The genotype $\times$ storage temperature interaction effect on ethylene evolution from scallops was highly significant (Table 2). Ethylene evolution from $B^{+} B^{+}$scallops was extremely low following storage at 5 and $12 \mathrm{C}$, whereas a dramatic stimulation of ethylene evolution occurred in $B B$ scallops following storage at 5C (Fig. 3, bottom).

Chen and Patterson (1985) reported that the duration of chilling required to elicit maximum ethylene evolution from leaves 


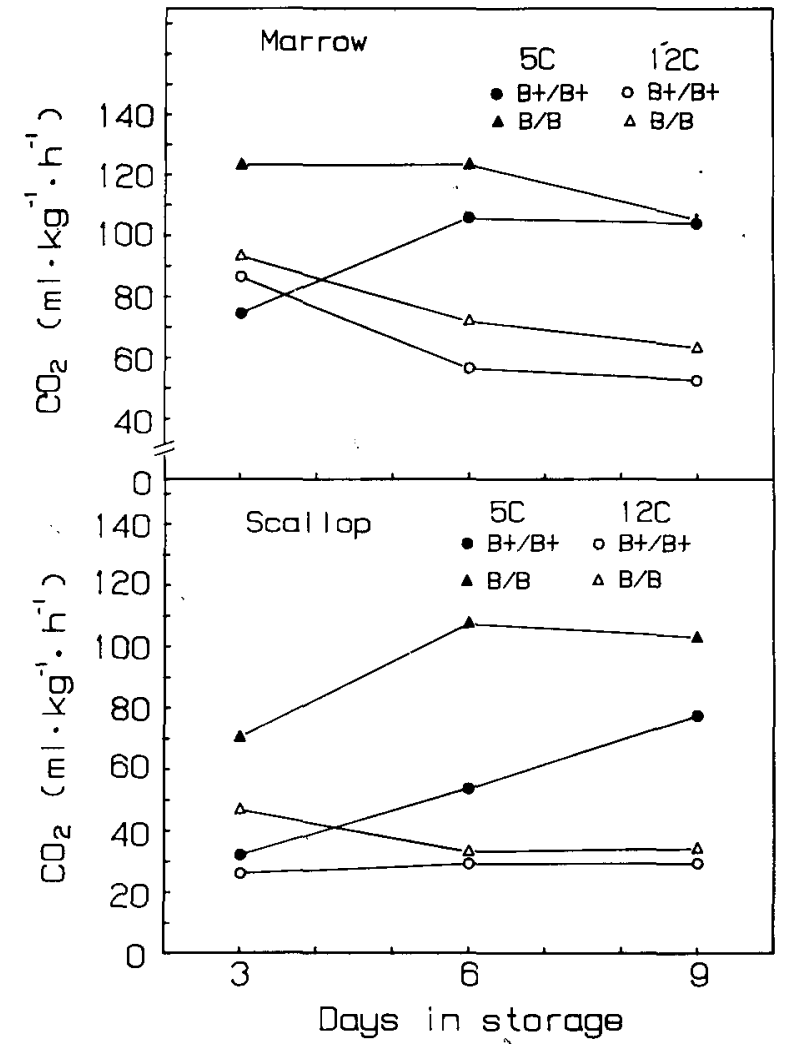

Fig. 2. Respiration rates of marrow-type (top) and scallop-type (bottom) summer squash with $(B B)$ and without $\left(B^{+} B^{+}\right)$gene $B$ at $15 C$ following storage at 5 and $12 \mathrm{C}$ for 3,6 , and 9 days. Values represent the means of four replicate samples.

of various species of Passiflora corresponded with known differences in chilling sensitivity. A difference in the timing of chilling-induced stimulation of ethylene was not detected in marrows; however, the storage temperature $\times$ storage duration interaction effect on ethylene evolution from marrows was highly significant. The rate of ethylene evolution from marrows was highest following 3 days of chilling and decreased with increased duration of chilling. A decrease in the rate of ethylene evolution following extended storage duration at chilling temperatures is characteristic of various chilling-sensitive tissues (Chen and Patterson, 1985; McCollum, 1989; Wang and Adams, 1980). Wang and Adams (1982) have shown in cucumber that this decrease in ethylene evolution is the result of an impairment of the ethylene-forming system. The timing of this decrease is indicative of the extent of CI and, therefore, a measure of chilling sensitivity. The greater sensitivity of marrows to chilling compared to scallops is reflected in the earlier chilling-induced stimulation and subsequent decrease in ethylene evolution.

Electrolyte leakage. In contrast to respiration and ethylene evolution, electrolyte leakage was not consistently influenced by storage temperature or gene $B$. Electrolyte leakage from marrows was not influenced by gene $B$, but the effect of storage temperature on electrolyte leakage from marrows was highly significant (Table 2). Electrolyte leakage from marrows was consistently higher following storage at $12 \mathrm{C}$ than at $5 \mathrm{C}$ (Fig. 4, top). An increase in leakage in response to storage at nonchilling temperature has also been detected in another summer squash cultivar (T.G.M., unpublished data). Olorunda and Looney (1977) reported that storage of winter squash at chilling temperatures

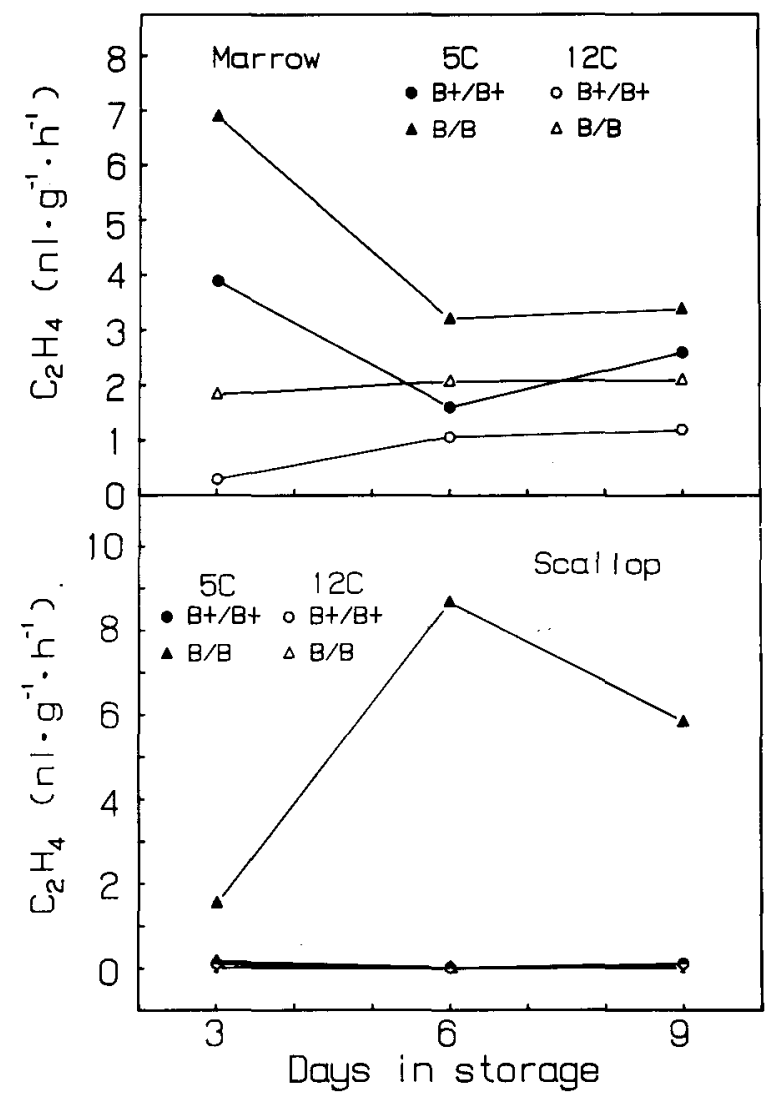

Fig. 3. Ethylene evolution from marrow-type (top) and scallop-type (bottom) summer squash fruit with $(B B)$ and without $\left(B^{+} B^{+}\right)$gene $B$ at $15 \mathrm{C}$ following storage at 5 and $12 \mathrm{C}$ for 3,6 , and 9 days. Values represent the means of four replicate samples.

had no effect on electrolyte leakage. According to Fukushima et al. (1977), the amount of exudate from cucumber fruit was higher following storage at $10 \mathrm{C}$ than at $5 \mathrm{C}$. In a subsequent study (Fukushima and Tsugiyama, 1977), leakage of Ca and $\mathrm{Mg}$ from cucumber fruit was higher at nonchilling than chilling temperatures. In the same study, leakage of $\mathrm{K}$ was similar at 5 and 10C. Summing the amount of specific ions that leaked revealed that leakage was higher at $10 \mathrm{C}$ than at $5 \mathrm{C}$. However, leakage from cucumber fruit was higher at $0 \mathrm{C}$ than at 5 or 10C. Pepper (Capsicum annuum) and eggplant (Solanum melongena) are examples of chilling-sensitive fruit in which electrolyte leakage does not increase in response to chilling (Murata and Tatsumi, 1979). Autio and Bramlage (1986) reported that chilling did not increase the amount of electrolyte leakage from immature "rin" tomato fruit. Electrolyte leakage is apparently not a useful index of CI in all chilling-sensitive tissues.

The genotype $\times$ storage temperature $\times$ storage duration linear interaction effect for electrolyte leakage from scallops was significant (Table 2). Electrolyte leakage was not influenced by storage temperature in $B^{+} B^{+}$scallops, but increased in response to chilling in $B B$ scallops (Fig. 4, bottom). This chilling-induced stimulation of leakage was similar to that reported for other chilling-sensitive fruit (Autio and Bramlage, 1986; Chan et al., 1985; King and Ludford, 1983). The chilling-induced increase in leakage in $B B$, but not in $B^{+} B^{+}$, scallops supports the hypothesis that gene $B$ enhances chilling sensitivity.

Results of this study confirm the report of Sherman et al. (1987) that marrows are more susceptible to CI than scallops and that gene $B$ increases susceptibility to $\mathrm{CI}$. Differences in 

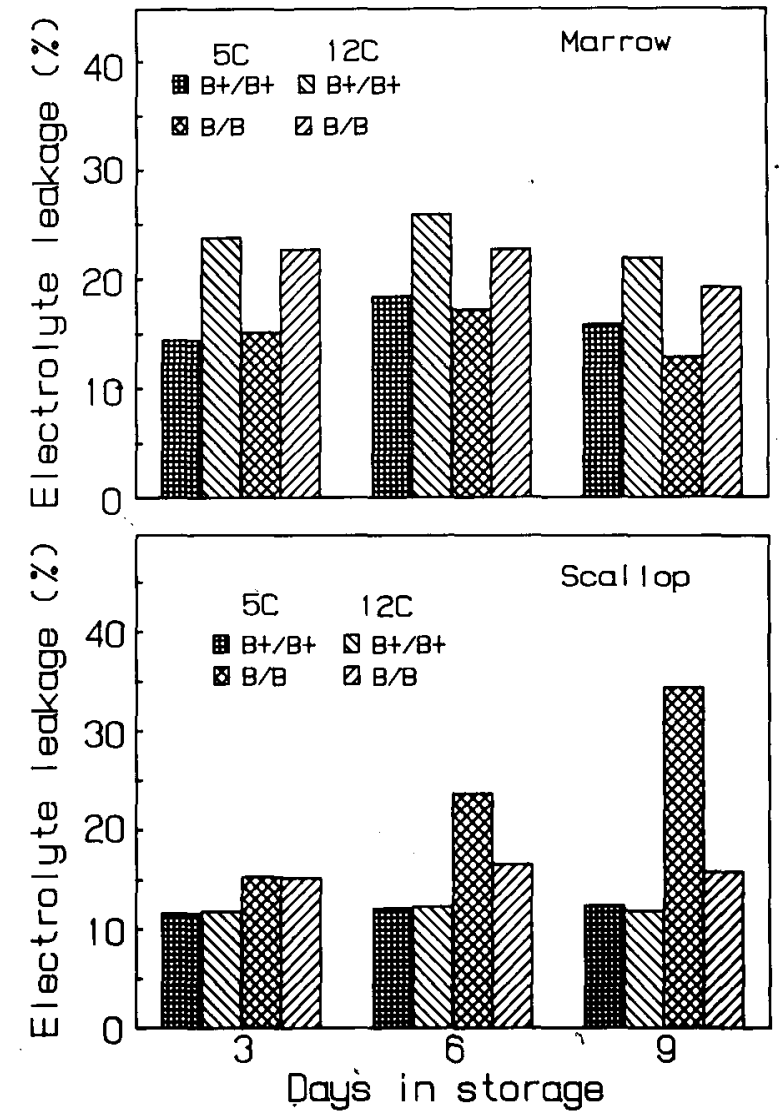

Fig.4. Electrolyte leakage from pericarp disks of marrow-type (top) and scallop-type (bottom) summer squash fruit with $(B B)$ and without $\left(B^{+} B^{+}\right)$gene $B$ following storage at 5 and $12 \mathrm{C}$ for 3 , 6, and 9 days. Values represent the means of four replicate samples.

susceptibility to CI among summer squash genotypes have practical significance in terms of postharvest handling. Increased susceptibility to CI effectively increases the perishability of the product. In addition, differences in susceptibility to CI among genotypes of the same species represent an attractive system for investigating the physiological basis of CI.

\section{Literature Cited}

Abeles, F.B. 1973. Ethylene in plant biology. Academic, New York. Autio, W.R. and W.J. Bramlage. 1986. Chilling sensitivity of tomato fruit in relation to ripening and senescence. J. Amer. Soc. Hort. Sci. 111:201-204.

Chan, H.T., S. Sanxter, and H.M. Couey. 1985. Electrolyte leakage and ethylene production induced by chilling injury of papayas. HortScience 20:1070-1072.

Chen, Y. and B.D. Patterson. 1985. Ethylene and 1-aminocyclopro- pane-1-carboxylic acid as indicators of chilling sensitivity in various plant species. Austral. J. Plant Physiol. 12:377-385.

Eaks, I.L. and L.L. Morris. 1956. Respiration of cucumber fruit associated with physiological injury at chilling temperature. Plant Physiol. 31:308-314.

Fukushima, T. and T. Tsugiyama. 1977. Chilling-injury in cucumber fruits. II. Chemical analyses of leakage substances and anatomical observation of symptoms. Scientia Hort. 6:199-206.

Fukushima, T., M. Yamazaki, and T. Tsugiyama. 1977. Chilling injury in cucumber fruits. I. Effects of storage temperature on symptoms and physiological changes. Scientia Hort. 6:185-197.

King, M.M. and P M. Ludford. 1983. Chilling injury and electrolyte leakage in fruit of different tomato cultivars. J. Amer. Soc. Hort. Sci. 108:74-77.

Lorenz, O.A. 1951. Chemical changes in early prolific summer squash during storage. Proc. Amer. Soc. Hort. Sci. 57:288-294.

McCollum, T.G. 1989. Physiological changes in yellow summer squash at chilling and nonchilling temperatures. HortScience 24:633-635.

Mencarelli, F. 1987. Effect of high $\mathrm{CO}_{2}$ atmospheres on stored zucchini squash. J. Amer. Soc. Hort. Sci. 112:985-988.

Mencarelli, F., W.J. Lipton, and S.J. Peterson. 1983. Responses of zucchini squash to storage in low- $\mathrm{O}_{2}$ atmospheres at chilling and nonchilling temperatures. J. Amer. Soc. Hort. Sci. 108:884-890.

Murata, T. and Y. Tatsumi. 1979. Ion leakage unchilled plant tissues, p. 141-151. In: J.M. Lyons, D. Graham, and J.K. Raison (eds.). Low temperature stress in crop plants. Academic, New York.

Olorunda, A.O. and N.E. Looney. 1977. Response of squash to ethylene and chilling. Ann. Applied Biol. 87:465-469.

Paris, H.S. 1986. A proposed subspecific classification for Cucurbita pepo. Phytologia. 61:133-138.

Paris, H.S., Y. Burger, Z. Karchi, and H. Nerson. 1985a. 'Benning's Yellow Tint' summer squash. HortScience 20:785-786.

Paris, H.S., H. Nerson, and Y. Burger. 1985b. Precocious caserta summer squash breeding line. HortScience 20:786.

Poenicke, E.F., S.J. Kays, D.A. Smittle, and R.E. Williamson. 1977. Ethylene in relation to postharvest quality deterioration in processing cucumbers. J. Amer. Soc. Hort. Sci. 102:303-306.

Saltveit, M.E. and R.F. McFeeters. 1980. Polygalacturonase activity and ethylene synthesis during cucumber fruit development and maturation. Plant Physiol. 66:1019-1023.

Sherman, M., G.W. Elmstrom, and J.J. Allen. 1985. Storage characteristics of three cultivars of yellow summer squash (Cucurbita pepo L.). Proc. Fla. State Hort. Soc. 98:216-218.

Sherman, M., H.S. Paris, and J.J. Allen. 1987. Storability of summer squash as affected by gene $B$ and genetic background. HortScience 22:920-922.

Shifriss, O. 1981. Origin, expression, and significance of gene $B$ in Cucurbita pepo L. J. Amer. Soc. Hort. Sci. 106:220-232.

Shifriss, O. 1988. On the emergence of gene $B$ cultivars in squash. HortScience 23:238.

Wang, C.Y. and D.O. Adams. 1980. Ethylene production by chilled cucumbers (Cucumis sativus L.). Plant Physiol. 66:841-843.

Wang, C.Y. and D.O. Adams. 1982. Chilling-induced ethylene production in cucumbers (Cucumis sativus L.). Plant Physiol. 69:424427. 